Newfoundland and Labrador Studies

\title{
Maura Hanrahan. Unchained Man: The Arctic Life and Times of Captain Robert Bartlett
}

James E. Candow

Volume 34, Number 1, 2019

URI: https://id.erudit.org/iderudit/1072441ar

DOI: https://doi.org/10.7202/1072441ar

See table of contents

Publisher(s)

Faculty of Arts, Memorial University

ISSN

1719-1726 (print)

$1715-1430$ (digital)

Explore this journal

Cite this review

Candow, J. (2019). Review of [Maura Hanrahan. Unchained Man: The Arctic Life and Times of Captain Robert Bartlett]. Newfoundland and Labrador Studies, 34(1), 171-173. https://doi.org/10.7202/1072441ar viewed online.

https://apropos.erudit.org/en/users/policy-on-use/ 
BOOK REVIEWS

Maura Hanrahan. Unchained Man: The Arctic Life and Times of Captain Robert Bartlett. St. John's: Boulder Publications, 2018. ISBN 978-1-927099-94-0

Unchained Man is the first major biography of Bob Bartlett since Harold Horwood's Bartlett: The Great Canadian Explorer (Toronto: Doubleday, 1977). While Horwood was not uncritical, Maura Hanrahan turns up the heat by focusing on the ways in which Bartlett's life demonstrates the concepts of colonialism, racism, sexism, and classism. Although she acknowledges his achievements as both an explorer and amateur scientist, she is critical of his role in "firsting," i.e., "discovering' places that are actually within the territory of others, as the Arctic was for the Inuit," and also of "seconding," or "relegating Inuit to the background in exploration narratives" (4). While admitting that she may be open to charges of "seconding" because her subject is a white male, she counters that she is obeying anthropologist Laura Nader's "call to study the colonizer."

The book begins with Bartlett's departure from New York in July 1908 as captain of the SS Roosevelt, bound for northern Ellesmere Island as part of Robert Edwin Peary's latest attempt to reach the North Pole. Hanrahan recaps the debate over whether Peary actually got to the Pole and, reflecting recent literature on the subject, observes that racism was "at the foundation of all exploration activity" (23), an exaggerated claim that would not have applied to the exploration of Antarctica in the period. She raises the concept of terra nullius, which holds that the Arctic was unoccupied and "available for the taking," and also "rendered Indigenous people ... invisible and, when visible, 
insignificant" (25). The Roosevelt's crew included Peary's valet, Matthew Henson, who despite being an African American had "internalized" (51) the racism of the period and who, like Peary, had an Inuk "wife." Sexism was racism's twin, for the Arctic was also "an exclusively male sphere in which white men [sic] could demonstrate and push their masculinity" (67).

Turning to Bartlett's Brigus origins, Hanrahan offers a detailed portrait of the "decidedly feminine" (78) household in which he was raised. She is nonetheless at pains to point out that the Bartlett women "were insulated from the realities that many of their neighbours faced and were capable of sounding patronizing" (97). She characterizes the innumerable acts of kindness by Bob's sisters towards the less fortunate as noblesse oblige motivated by "their keen awareness of their social station" (98). Similarly, Bartlett's description of the nineteenth century as Newfoundland's golden age "overlooked ... social inequalities in Brigus and elsewhere" (123).

It is indisputable that colonialism, racism, and sexism were inherent in Arctic exploration, and Hanrahan legitimately highlights their existence; given Bartlett's iconic status, this perspective also shows courage on her part. Nonetheless, her animadversions against Bartlett and his family for their classism are petty and beside the point, and she is also prone to overstatement where racism is concerned. She uses great uncle Nathan Norman's support for the trans-Newfoundland railway as an opportunity to note that the interior through which it passed was "the domain of the Mi'kmaq" and thus "belonged to others" (130). An account of Bartlett's role in a motion picture prompts her to observe that the film's director, Varrick Frissell, "helped establish Yale, the residential school in North West River, Labrador, which was the subject of a 21st-century class action lawsuit brought by its Indigenous former students and a subsequent apology by Canadian prime minister Justin Trudeau" (216). We are a long way from the North Pole here.

Hanrahan relies too much on speculation and amateur psychology, notably concerning Bartlett's youthful bedwetting, whether he had a child with an Inuk woman, and whether he might have been gay. As 
evidence for the latter, she cites his "high-pitched voice" (254); a conversation with author Paul O'Neill, who informed her that a contemporary of Bartlett's "told him Bartlett was homosexual" (255); and correspondence between Bartlett and a male admirer that could be read many ways. I do not know or care if Bartlett was gay, but I do know that innuendo, gossip, and selectivity are unacceptable as proof that he was.

A number of factual errors further detract from the book's credibility. Captain John Bartlett went to the Arctic with Dr. Israel Hayes in 1869, not "in the 1850s" (34). The Education Act of 1836 did not establish "Newfoundland's denominational school system" (131). To the contrary, it created a non-denominational system that stood until 1843. Her account of Bjarne Mamen's role in the Karluk disaster is badly flawed, and not once does she get the name of Bartlett's schooner, the Effe M. Morrissey, right. That is inexcusable given that the Morrissey, as she acknowledges, was Bartlett's "true love" (248).

Except for an arresting cover, Hanrahan and her publisher have done readers few favours. The maps, including one of Newfoundland and Labrador placing Harbour Grace north of Grates Cove, are appalling. The employment of imperial measure instead of metric, and of Fahrenheit instead of Celsius, is outdated, as is the use of $\mathrm{BC}$ in dates. And the section entitled "Ancestry of Captain Robert Abram Bartlett" is unorthodox and could have used a standard genealogical chart.

As a vehicle for consciousness-raising, Unchained Man is a useful addition to the Bartlett canon. But hang onto your Horwood, which is looking more and more like a masterpiece of Newfoundland biography.

James E. Candow Parks Canada (Retired) 